\title{
Effect of Peptides and Amino Acids Produced \\ by Lactobacillus casei in Milk on the Acid \\ Production of Bifidobacteria
}

\author{
Cheng-Chuan Cheng and Taro Nagasawa \\ Department of Agricultural Chemistry, Faculty of Agriculture, \\ Tamagawa University, Machida-shi 194
}

(Received October 31, 1983)

\begin{abstract}
It was found that the growth of bifidobacteria was greatly stimulated in the mixed incubation with Lactobacillus casei. Hence the peptides and free amino acids isolated from the culture filtrate prepared from the incubated milk with $L$. casei were investigated in relation to the stimulation on the acid production of bifidobacteria. Bifidobacterium breve, $B$. infantis, and Lactobacillus casei were used as test organisms. The preparation of culture filtrate was performed by means of DAHIYA and SPECK, and the removal of free amino acids from culture filtrate by the method of Mariovirz and Steingerg. The main results obtained were as follows: 1. Additions of the culture filtrate containing peptides and amino acids prepared from the incubated milk with $L$. case $i$ and the free amino acids-removed culture filtrate gave appreciable stimulation for the acid production of bifidobacteria over those of control, and the degree of stimulation was maximum with the addition of untreated filtrate at $24 \mathrm{hr}$ of incubation. But little difference was observed in the stimulation between two filtrates after $48 \mathrm{hr}$ of incubation. 2. In the case of the addition of single amino acid or the omission in turn of single amino acid from a mixture of amino acids, the stimulation on the acid production of bifidobacteria was observed to be highest for cystine among 18 amino acids, followed by methionine, lysine, alanine, and histidine. 3. The stimulatory effect by cystine was greater in $B$. infantis than in $B$. breve. Isoleucine or tryptophan gave not only the reduction of acid production of $B$. infantis but also considerably reduced the stimulation by cystine with the increasing amount of isoleucine or tryptophan. 4. Active fractions, having stimulation on the acid production, obtained from gel filtration of the free amino acids-removed culture filtrate with Sephadex G-15 contained five peptides, ranging from 948 to 2,319 in molecular weights. Lys, Met, Ala, Leu and Val of the amino acids detected in the peptides were considered to stimulate the acid production of bifidobacteria.

Jpn. J. Zootech. Sci., 55 (5): 339-349, 1984
\end{abstract}

When bifidobacteria were incubated with Lactobacillus casei in milk, the growth and acid production of bifidobacteria were greatly stimulated ${ }^{11}$. Although there seemed to be many factors influencing to the growth and acid production of bifidobacteria, the low molecular weight nitrogenous compounds produced by $L$. case $i$ in milk, particularly peptides and amino acids which from the viewpoint of nitrogen source were considered to be more important for the stimulation were isolated and characterized to gain more information about the roles played by the stimulants such as peptides and amino acids.

\section{Materials and Methods}

\section{Microorganisms}

The strains of Lactobacillus casei (MT-8105), Bifidobacterium breve (MT-17), 
and Bifidobacterium infantis (MT-60) used in this study were kindly presented by the Central Research Laboratory of Morinaga Milk Industry Co., Tokyo.

Media and culture conditions

The stock media and pre-cultures of tested bacteria have been described previously ${ }^{1)}$.

\section{Determination of acidity and nitrogen}

Stimulation effect on the acid production was evaluated by the determination of titratable acidity of incubated milk which was measured by a standard procedure with $0.1 \mathrm{~N} \mathrm{NaOH}$ using phenolphthalein as an indicator ${ }^{2)}$. Nitrogen was determined by a standard micro-Kjeldahl procedure ${ }^{2)}$.

Measurement of stimulatory activities of culture filtrates, gel-fractions, and amino acids

One $\mathrm{m} l$ of the solution containing the test materials such as culture filtrates, gelfractions, and amino acids was sterilized by passage through Millipore filter (Millipore Corp. Millex-Ha, $0.45 \mu \mathrm{m}$ Filter Unit) and then was added to $9 \mathrm{ml}$ of milk (reconstituted non-fat milk containing $11 \%$ of solids-not-fat).

The milk inoculated with $1 \%$ of active bifidobacteria was incubated at $37^{\circ} \mathrm{C}$ under anaerobic conditions with the addition of sterilized liquid paraffin. After incubation, the acid production was determined by titration with $0.1 \mathrm{~N} \mathrm{NaOH}$.

Isolation of stimulants

1) Preparation of culture filtrate

The procedure of DaHIYA and SPECK $^{3)}$ was used for the preparation of culture filtrate. After three successive subcultures, the cells of $L$. case $i$ were centrifuged, washed, and suspended in the sterilized phosphate buffer $(\mathrm{pH} \mathrm{6.8)}$. The suspension was added $(3 \%, \mathrm{v} / \mathrm{v})$ into $500 \mathrm{~m} l$ of sterilized reconstituted non-fat milk ( $10 \%$ solids).

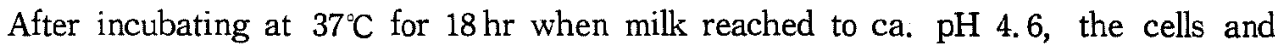
casein were removed by centrifugation. The supernatant was condensed to $100 \mathrm{ml}$, and $400 \mathrm{ml}$ of a cold acetone-ethanol mixture $(3: 1)$ was added. The precipitate was allowed to develop in a refrigerator for $4 \mathrm{hr}$ with occasional shaking, and then the supernatant was obtained through filter-paper. The filtrate was evaporated to dryness under vacuum with rotary evaporator, and its volume was made again to $100 \mathrm{~m} l$ after adjusting to $\mathrm{pH} 7.0$. The filtrate was passed through an ion exchange resin (Amberlite IRC 120) in the $\mathrm{H}^{+}$cycle. The column was washed with distilled water until the washings showed no lactose by the Molisch test. The material held on the column was eluted with $4 \%$ aqueous ammonia solution, and the ammonia solution of eluate was removed by drying under vacuum. The eluate was concentrated under vacuum to near dryness, and the volume was made to $20 \mathrm{ml}$ by the addition of distilled water.

2) Removal of the free amino acids from the culture filtrate

The filtrate prepared by the method mentioned above was separated into two portions. One portion was treated with ninhydrin to remove free amino acids by the method of Markovitz and SteinberG ${ }^{4}$, and the other portion was left intact. Namely, 
$0.5 \mathrm{~g}$ of ninhydrin was added to the filtrate which was adjusted to $\mathrm{pH} 2.5$ with citrate buffer, and the mixture was heated for $10 \mathrm{~min}$ in a boiling water bath. The reaction mixture was rapidly cooled, filtered, extracted with diethyl ether to remove unreacted ninhydrin, and freeze dried. In the case of measurement of the stimulation by culture filtrate, the freeze dried compounds were diluted with distilled water to the same volume of culture filtrate before the ninhydrin treatment.

3) Fractionation of the free amino acids-removed culture filtrate with Sephadex G-15

The free amino acids-removed culture filtrate was applied to a column $(2 \times 70 \mathrm{~cm})$ of Sephadex G-15. The column was eluted with distilled water at a flow rate of 2 $\mathrm{ml} / \mathrm{min}$ at room temperature $\left(15^{\circ} \mathrm{C}\right)$. The positive biuret reaction of fractions were detected by the method of MATHeson and TATTRIE ${ }^{5}$, using ninhydrin reagent.

4) Isolation of peptides by low-voltage electrophoresis and paper chromatography

The active fractions from 3) were mapped by means of electrophoresis chromatography. Low-voltage electrophoresis $\left.{ }^{6}\right)$ was performed at $500 \mathrm{~V}(25 \mathrm{~V} / \mathrm{cm})$ for $45 \mathrm{~min}$ with chromatography paper (No. 51, Toyo Roshi, Tokyo) in an Electrophoretic apparatus (SJ-1060 A, Atto Co., Tokyo). Pyridine-acetic acid-water (20:0.8: 180, $\mathrm{pH}$ 6.5) was used as an electrophoresis buffer. The solvent for ascending paper chromatography in the second dimension was propanol-water $(7: 3)$. Peptides were detected after spraying the dried papers with ninhydrin-cupric nitrate reagent ${ }^{7)}$ and heating for $15-20 \mathrm{~min}$ in an oven at $90^{\circ} \mathrm{C}$.

5) Amino acid analysis

Determination of the amino acids in acid hydrolysates of the peptides was made with an amino acid analyzer (KLA-5, Hitachi, Tokyo) after the peptides were hydrolysated using the method of MOORE and STEIN ${ }^{8}$.

\section{Results and Discussion}

1. The stimulation for the acid production of bifidobacteria by the culture-filtrates from L. casei

The content of the free amino acids in the culture filtrate obtained from the incubated milk with $L$. case $i$ was found to be about 3 times more than that originally present in milk (Table 1). On the other hand, about $97 \%$ amino acids and $15 \%$ of peptides (data not shown) contained in the filtrate were lost by the treatment with ninhydrin.

When comparing the free amino acid composition of the culture filtrate with that of skim milk, it was interesting to note that the concentrations of glycine and in particular cystine in the culture filtrate were slightly lower than those of skim milk in spite of the copious quantities of low molecular weight nitrogenous compounds produced by $L$. casei. This finding seems to be of particular importance for the improvement of growth of bifidobacteria from the viewpoint of supplying cystine.

As shown in Table 1, this phenomena may be due to the fact that L. casei, like other bacteria, hydrolyses predominantly casein, which has the low level of cystine 
Table 1. Free amino acid composition of skim milk before and after incubation with $L$. casei for $24 \mathrm{hr}$ at $37^{\circ} \mathrm{C}$

\begin{tabular}{cccc}
\hline $\begin{array}{c}\text { Amino acid } \\
(\mathrm{mg} / 100 \mathrm{~m} l)\end{array}$ & \multicolumn{2}{c}{ L. casei } & Skim milk \\
\cline { 2 - 3 } UTN & TN & (no inoculum) \\
\hline Lys & 0.758 & 0.013 & 0.075 \\
His & 0.093 & 0.012 & 0.066 \\
Arg & 0.060 & $\mathrm{c}$ & 0.066 \\
Asp & 0.072 & $\mathrm{c}$ & 0.117 \\
Thr & 0.031 & $\mathrm{c}$ & 0.121 \\
Ser & 0.032 & $\mathrm{c}$ & 0.124 \\
Glu & 0.471 & $\mathrm{c}$ & 1.518 \\
Pro & 0.558 & $\mathrm{c}$ & 0.048 \\
Gly & 0.142 & $\mathrm{c}$ & 0.402 \\
Ala & 0.501 & 0.014 & 0.230 \\
Cys & 0.048 & $\mathrm{c}$ & 0.068 \\
Val & 0.830 & 0.024 & 0.154 \\
Met & 0.282 & 0.016 & 0.053 \\
Ile & 0.538 & 0.009 & 0.068 \\
Leu & 3.179 & 0.016 & 0.067 \\
Tyr & 0.512 & 0.090 & 0.077 \\
Phe & 1.034 & 0.090 & 0.053 \\
Total & 9.141 & 0.284 & 3.307 \\
\hline
\end{tabular}

UTN: untreated filtrate with ninhydrin. TN: treated filtrate with ninhydrin. c: trace.

compared with that of whey protein, rather than whey protein when the milk was incubated with $L$. casei. In the case of evaluating milk as a cystine source, this is an essential point to which more attention be paid in mixed incubations with bifidobacteria and $L$. casei.

Mills and THOMAS $^{9)}$ reported that the free amino acids initially present in milk were an important nitrogen source for growth of Streptococcus cremoris at low cell densities, and peptide originally present in milk supplied an almost constant proportion of nitrogen for growth. With regard to the stimulation on the acid production by bifidobacteria, additions of both ninhydrin-treated (nitrogen content : 0.045 $\mathrm{mg} / \mathrm{ml}$ ) and untreated (nitrogen content: $0.060 \mathrm{mg} / \mathrm{ml}$ ) filtrates to the milk inoculated with bifidobacteria gave appreciable stimulation for the acid production of bifidobacteria over those of control (water added), and the degree of stimulation was maximum with the addition of untreated filtrate in $B$. breve and $B$. infantis at $24 \mathrm{hr}$ of incubation (Fig. 1). Accordingly, the finding that untreated filtrate showed higher stimulation for acid production by bifidobacteria as compared with that of treated filtrate is considered to be due to the difference in the contents of free amino acids between untreated and treated filtrates. Namely, the ratio of the content of amino acid in ninhydrin treated filtrate to that of untreated filtrate was only $3 \%$ as shown in Table 

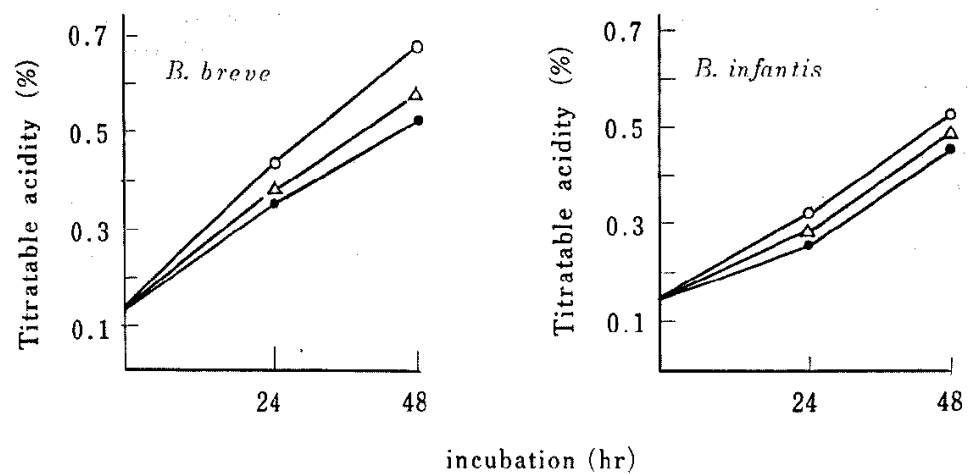

Fig. 1. Effect of the culture filtrates produced by $L$. casei on the acid production of $B$. breve and $B$. infantis. - - , untreated filtrate with ninhydrin; $-\Delta-$, treated filtrate with ninhydrin; $-\longrightarrow$, control.

1. But after $48 \mathrm{hr}$ of incubation, little difference in the stimulation on the acid production by bifidobacteria was observed both in the milks added with the treated filtrate and with the untreated one. Therefore, it is presumed that the free amino acids were utilized during the early stage of incubation $(24 \mathrm{hr}$ ), and then peptides became available during the prolonged incubation $(48 \mathrm{hr})$.

\section{The effect of the amino acids added on the acid production of bifidobacteria}

In order to gain more knowledge about the stimulatory effect of amino acids on the acid production of $B$. breve and $B$. infantis in milk, single amino acid or a mixture of amino acids was added to milk. The amount of each amino acid added was $5 \mathrm{mg} / 100 \mathrm{ml}$ and for cystine was $0.625 \mathrm{mg} / 100 \mathrm{ml}$. As shown in Table 2, addition of cystine gave the remarkable stimulation on the acid production of $B$. breve (approx. $68 \%$ ) and $B$. infantis (109\%) over that of control. On the contrary, omission test with cystine resulted in the decrease of acid production both in $B$. breve (38\%) and in $B$. infantis $(60 \%)$, respectively, as compared with that of control. Therefore, the effect of cystine added on the acid production of $B$. infantis seemed to be greater than that of $B$, breve.

The single and omission tests with methionine on the acid production of $B$. breve showed $40 \%$ of increase and $35 \%$ of decrease compared to control, respectively. But in $B$. infantis, $30 \%$ of increase and $20 \%$ of decrease were observed with methionine. Lysine or alanine for $B$. breve and histidine for $B$. infantis showed higher rate of acid production than control by over $10 \%$. The other amino acids tested showed little changes on acid production of $B$. breve and $B$. infantis except isoleucine and tryptophan for $B$. infantis. Namely, addition of isoleucine and tryptophan decreased the acid production of $B$. infantis by $5 \%$ for isoleucine and $4 \%$ for tryptophan, respectively, compared with that of control. While the removal of isoleucine or tryptophan from a mixture of 18 amino acids resulted in an increase of acid production by $7 \%$ for isoleucine or tryptophan, respectively. In view of these results, isoleucine and tryptophan were considered to be the only two amino acids who showed the inhibitory 
Table 2. Stimulation on acid production (\%) of $B$. breve and $B$. infantis by addition of single amino acid or omission in turn of single amino acid from a mixture of amino acids

\begin{tabular}{|c|c|c|c|c|c|}
\hline \multirow{2}{*}{$\begin{array}{l}\text { Amino } \\
\text { acid }\end{array}$} & \multicolumn{2}{|c|}{ Single test } & \multirow{2}{*}{ Amino acid } & \multicolumn{2}{|c|}{ Omission test } \\
\hline & B. breve & B. infantis & & B. breve & B. infantis \\
\hline Control & $100(0.342 \%)$ & $100(0.251 \%)$ & 18 amino acids & $100(0.963 \%)$ & $100(0.793 \%)$ \\
\hline +Lys & 114 & 106 & - Lys & 80 & 75 \\
\hline$+\mathrm{His}$ & 107 & 110 & - His & 90 & 65 \\
\hline+ Arg & 105 & 104 & $-\operatorname{Arg}$ & 98 & 70 \\
\hline+ Asp & 104 & 101 & $-A s p$ & 98 & 90 \\
\hline+ Thr & 103 & 100 & - Thr & 98 & 88 \\
\hline+ Ser & 103 & 104 & - Ser & 99 & 77 \\
\hline+ Glu & 103 & 104 & - Glu & 98 & 100 \\
\hline+ Pro & 103 & 101 & - Pro & 99 & 91 \\
\hline + Gly & 103 & 104 & - Gly & 99 & 95 \\
\hline +Ala & 114 & 104 & - Ala & 88 & 86 \\
\hline+ Cys & 168 & 209 & -Cys & 62 & 40 \\
\hline+ Val & 106 & 104 & - Val & 98 & 96 \\
\hline+ Met & 140 & 103 & - Met & 65 & 79 \\
\hline+ Ile & 106 & 95 & -Ile & 86 & 107 \\
\hline+ Leu & 105 & 104 & -Leu & 90 & 70 \\
\hline+ Tyr & 100 & 104 & - Tyr & 99 & 89 \\
\hline+ Phe & 101 & 104 & - Phe & 98 & 100 \\
\hline+ Try & 101 & 96 & $-\operatorname{Try}$ & 98 & 107 \\
\hline
\end{tabular}

Incubation was performed at $37^{\circ} \mathrm{C}$ for $24 \mathrm{hr}$. Each amino acid added was $5 \mathrm{mg} / 100 \mathrm{~m} l$ medium except cystine $(0.625 \mathrm{mg} / 100 \mathrm{~m} l)$.

activity on the acid production of $B$. infantis when added separately to the milk.

Furthermore, in the case of $B$. infantis, it was of interest to note that the stimulation effect of added cystine on the acid production was reduced with the increasing amount of isoleucine or tryptophan added. For example, when the amount of isoleucine added was increased from $1.0 \mathrm{mg}$ to $10.0 \mathrm{mg}$, stimulatory effect by cystine was reduced from $91 \%$ to $87 \%$ as shown in Table 3 .

Table 3. Effect of addition of isoleucine or tryptophan on acid production of $B$. infantis in skim milk added with cystine

\begin{tabular}{|c|c|c|c|c|c|}
\hline $\begin{array}{l}\text { Amino acid } \\
\text { added } \\
(\mathrm{mg} / 100 \mathrm{~m} l)\end{array}$ & $\begin{array}{c}\text { Titratable } \\
\text { acidity } \\
(\%)\end{array}$ & $\begin{array}{l}\text { Rate } \\
(\%)\end{array}$ & $\begin{array}{l}\text { Amino acid } \\
\text { added } \\
(\mathrm{mg} / 100 \mathrm{ml})\end{array}$ & $\begin{array}{c}\text { Titratable } \\
\text { acidity } \\
(\%)\end{array}$ & $\begin{array}{l}\text { Rate } \\
(\%)\end{array}$ \\
\hline $\begin{array}{l}\text { Control } \\
\text { (Cys: } 0.625 \mathrm{mg})\end{array}$ & 0.529 & 100 & $\begin{array}{l}\text { Control } \\
\text { (Cys: } 0.625 \mathrm{mg})\end{array}$ & 0.529 & 100 \\
\hline Cys +Ile & & & Cys + Try & & \\
\hline $1.0 \mathrm{mg}$ & 0.482 & 91 & $1.0 \mathrm{mg}$ & 0.512 & $97^{\circ}$ \\
\hline $2.5 \mathrm{mg}$ & 0.474 & 90 & $2.5 \mathrm{mg}$ & 0.502 & 95 \\
\hline $5.0 \mathrm{mg}$ & 0.468 & 89 & $5.0 \mathrm{mg}$ & 0.500 & 9. \\
\hline $10.0 \mathrm{mg}$ & 0.460 & 87 & $10.0 \mathrm{mg}$ & 0.486 & 92 \\
\hline
\end{tabular}

Incubation was performed at $37^{\circ} \mathrm{C}$ for $24 \mathrm{hr}$. 


\section{Stimulation on Acid Production of Bifidobacteria}

According to the results of the minimal nutritional requirements of Lactobacillus bifidus reported by HASSINEN et al. ${ }^{10}$ ), it was found that cystine (cysteine) was the only amino acid required for the growth of the strains of $L$. bifidus, and also the requirement for cystine was specific as evidenced by the inactivity of the compounds of closely related chemical structure such as homocysteine and $\beta$-mercaptoethylamine. In the present study, it was recognized that cystine was the most effective among 18 amino acids tested for acid production of $B$. breve and $B$. infantis in milk, but the mechanism of cystine contribution for the growth of bifidobacteria has not yet been elucidated.

$\mathrm{MADA}^{11)}$ reported that omission test with aspartic acid showed $50 \%$ reduction of acid production by bifidobacteria. On the contrary, the reduction rate was only $2 \%$ and $10 \%$ for $B$. breve and $B$. infantis, respectively, in the omission test with aspartic acid as indicated in Table 2. Thus, the suggestion made by MADA was not supported by the results obtained in the present investigation.

3. Purification of peptides and its stimulatory effect on acid production of bifidobacteria

1) Sephadex column chromatography

As Fig. 2 indicated, two peaks indicating positive reaction with ninhydrin were found in the fractions obtained from gel-filtration of the amino acids-removed culture filtrate on Sephadex G-15. Namely, one peak was from tube no. 16 to 22 and the other from tube no. 23 to 34 . Moreover, the fractions from tube no. 17 to 20 (A) and from tube no. 27 to 30 (B) were collected as test material, respectively.

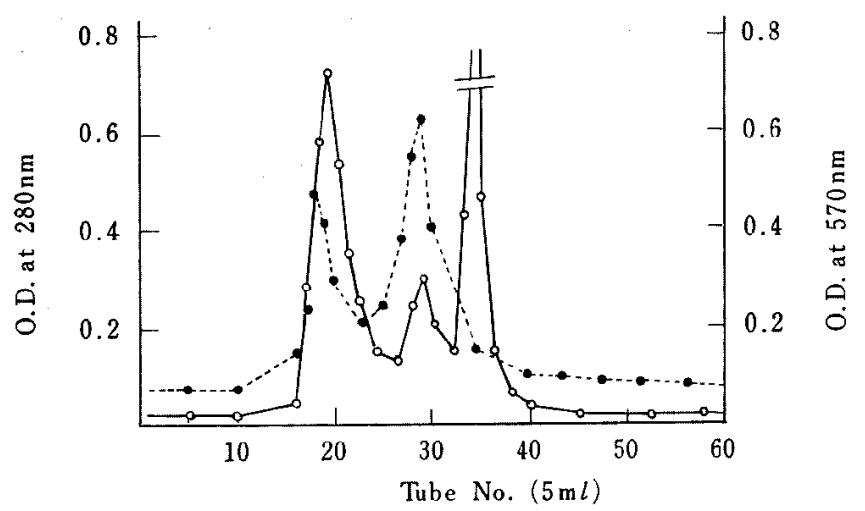

Fig. 2. Elution profile of the amino acids-removed culture filtrate on a Sephadex G-15 column $(2 \times 70 \mathrm{~cm})$. Elution was performed with distilled water. -o-, absorbance at $280 \mathrm{~nm}$. ...., absorbance at $570 \mathrm{~nm}$.

Fig. 3 showed that stimulation for the acid production of $B$. breve and $B$. infantis was observed in the milk, to which the different peaks ( $A$ and $B$ ) were added separately, after $24 \mathrm{hr}$ of incubation, and also the stimulation was higher in B than in A. Accordingly, it seemed to indicate that the fractions contained in A and B possessed growth stimulants for bifidobacteria such as peptides. 

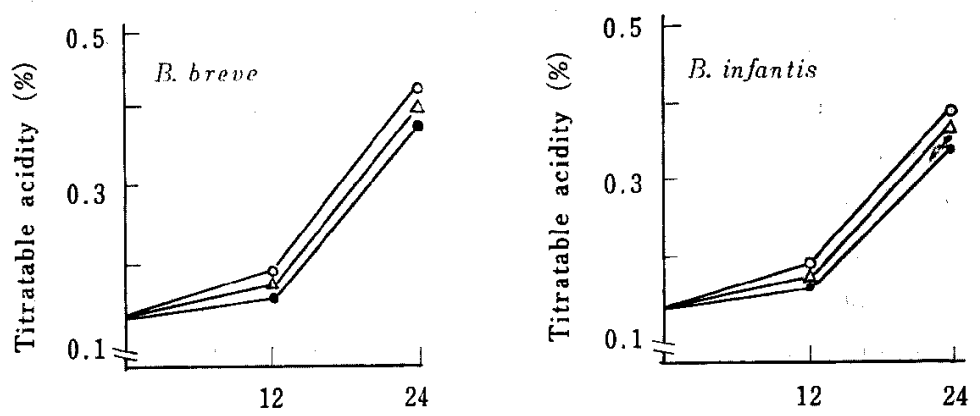

incubation ( $\mathrm{hr}$ )

Fig. 3. Acid production of $B$. breve and $B$. infantis by the addition of fractions from chromatography on a Sephadex G-15 column. Fractions added contained $7.5 \mu \mathrm{g} / \mathrm{ml}$ of nitrogen. - $\Delta-$, fraction of tube no. $17-20 .-0-$, fraction of tube no. $27-30$. - - , control.

2) Low-voltage electrophoresis and paper chromatography of peptides

Five distinct zones of peptide indicating positive biuret reaction were detected both in $\mathrm{A}$ and $\mathrm{B}$, using low-voltage electrophoresis and paper chromatography, respectively. By means of electrophoresis, the four ninhydrin positive zones from 1 to 4, all migrating toward anode, were separated equally in A and B. The three of these four zones (II, III andIV) were not separated further into additional zones even after paper chromatography. On the other hand, zone 1 was separated further into zones $I_{1}$ and $I_{2}$ by means of paper chromatography, as Rf values in Table 4 indicated. However, as shown in Fig. 4, the main components were judged to be zone $I_{1}$ and zone $\mathrm{I}_{2}$ in $\mathrm{A}$, and zones: II, III and IV in B, mainly based on the quantitative viewpoint of the peptide. Therefore, zones $I_{1}$, and $I_{2}$, and zones II, III, and IV were obtained from A and B, respectively, in larger quantities by preparative low-voltage electrophoresis and paper chromatography for the further study concerning the amino acid composition. But the homogeneity of each of the peptides obtained was not ascertained due to the distinctive difference in $\mathrm{Rf}$ value of each peptide.

Table 4. Migration distances ${ }^{\mathrm{a}}$ and $\mathrm{Rf}$ values $^{\mathrm{b}}$ of zones separated by low-voltage electrophoresis and paper chromatography

\begin{tabular}{ccc}
\hline Zone & Rf & Migration distance $(\mathbf{c m})$ \\
\hline $\mathrm{I}_{1}$ & 0.40 & 3.5 \\
$\mathrm{I}_{2}$ & 0.64 & 3.5 \\
II & 0.46 & 5.8 \\
III & 0.54 & 10.2 \\
IV & 0.50 & 12.5 \\
\hline
\end{tabular}

${ }^{2}$ Low-voltage electrophoresis, $\mathrm{pH} 6.5,500 \mathrm{~V}(25 \mathrm{~V} /$ $\mathrm{cm}), 45 \mathrm{~min}$. 'Solvent, propanol-water $(7: 3)$. 
Stimulation on Acid Production of Bifidobacteria

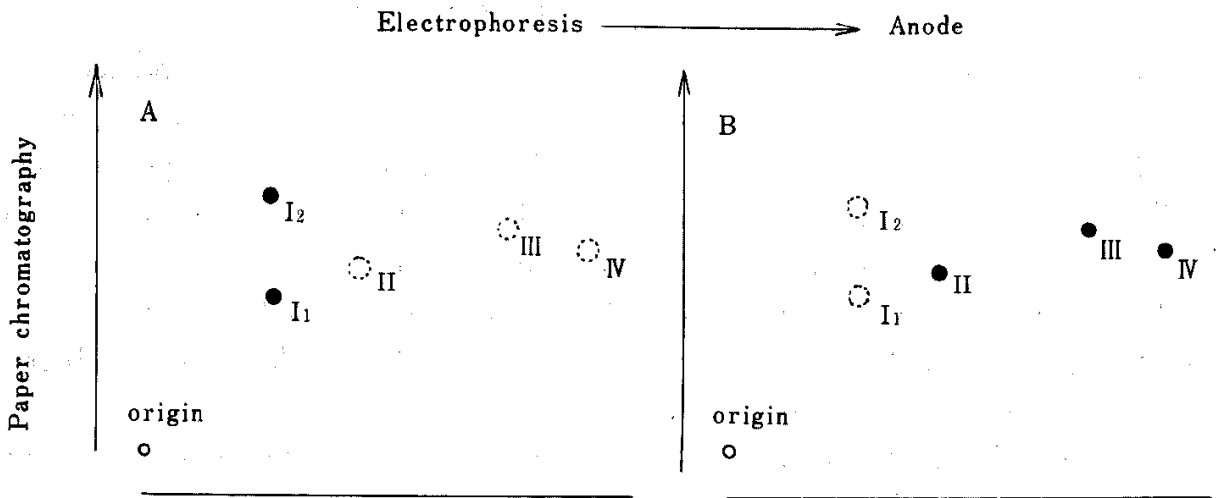

Fig. 4. Representation of a two-dimensional chromatogram of the peptides from Sephadex G-15 column (A: fractions of tube no. 17-20; B: fractions of tube no. 27-30); electrophoresis performed at $\mathrm{pH} 6.5$ in pyridine-acetic acid-water $(20: 0.8: 180), 500 \mathrm{~V}(25 \mathrm{~V} / \mathrm{cm}), 45 \mathrm{~min}$ followed by chromatography in propanol-water $(7: 3)$. O: trace.

3) Amino acid composition of peptides and its effect on the acid production

The amino acid composition of each of the five peptides was presented in Table 5. Each of the peptides differed not only in amino acid composition but also the ratio of the acids in the peptides varied. When the five peptides were hydrolysed into

Table 5. Amino acid composition of peptides $\mathrm{I}_{1}, \mathrm{I}_{2}$, II, III, and $\mathrm{IV}^{2}$ from culture filtrate produced by L. casei

\begin{tabular}{lccccc}
\hline \multirow{2}{*}{ Amino acid } & \multicolumn{5}{c}{ Peptides } \\
\cline { 2 - 6 } & $\mathrm{I}_{1}$ & $\mathrm{I}_{2}$ & $\mathrm{II}$ & $\mathrm{II}$ & $\mathrm{IV}$ \\
\hline Lys & $1.0^{\mathrm{b}}$ & $\mathrm{c}$ & 2.4 & 1.2 & $\mathrm{c}$ \\
His & $\mathrm{c}$ & $\mathrm{c}$ & $1.0^{\mathrm{b}}$ & $\mathrm{c}$ & $\mathrm{c}$ \\
Arg & 1.0 & $\mathrm{c}$ & 1.1 & $\mathrm{c}$ & $\mathrm{c}$ \\
Asp & 1.1 & 1.3 & 1.2 & 1.4 & 1.9 \\
Thr & 1.2 & $\mathrm{c}$ & 1.2 & $1.0^{\mathrm{b}}$ & $1.0^{\mathrm{b}}$ \\
Ser & 1.2 & 1.3 & 2.4 & 1.0 & 1.2 \\
Glu & 2.0 & 3.3 & 2.1 & 2.3 & 2.0 \\
Pro & 1.0 & $\mathrm{c}$ & 1.3 & $\mathrm{c}$ & $\mathrm{c}$ \\
Gly & 1.5 & 1.3 & 2.2 & 2.8 & 2.2 \\
Ala & 1.3 & 1.3 & 2.3 & 1.3 & 1.9 \\
Cys 1/2 & $\mathrm{c}$ & $\mathrm{c}$ & $\mathrm{c}$ & $\mathrm{c}$ & $\mathrm{c}$ \\
Val & 1.3 & $1.0^{\mathrm{b}}$ & 1.3 & 1.0 & 1.1 \\
Met & 1.2 & $\mathrm{c}$ & $\mathrm{c}$ & $\mathrm{c}$ & $\mathrm{c}$ \\
Ile & 1.2 & $\mathrm{c}$ & 1.1 & $\mathrm{c}$ & $\mathrm{c}$ \\
Leu & 1.2 & 1.1 & 2.4 & 1.1 & 1.0 \\
Tyr & 1.1 & $\mathrm{c}$ & 1.2 & $\mathrm{c}$ & $\mathrm{c}$ \\
Phe & 1.2 & $\mathrm{c}$ & 1.1 & $\mathrm{c}$ & $\mathrm{c}$ \\
Approx. & 1,913 & 948 & 2,319 & 1,162 & 1,163 \\
mol. wet. & & & & & \\
\hline
\end{tabular}

apeptides were acid hydrolyzed $24 \mathrm{hr}$ at $110^{\circ} \mathrm{C}$. 'Calculated by dividing the micromolar values by the micromolar value of the amino acid present in least abundance. "Indicates a negligible quantity. 


\section{Cheng and Nagasawa}

their constitutive amino acids, Lys, Met and Ala of the amino acids detected in them were considered to be most effective for the stimulation on the acid production of bifidobacteria, as shown in Table 2 . Lys was contained in peptides $I_{1}$, II and III, while Met in peptide $I_{1}$ only. Seven amino acids found common in all peptides were as follows: Asp, Ser, Glu, Gly, Ala, Val, and Leu. Table 2 also indicated that Ala of these seven amino acids showed the considerable stimulation on the acid production of bifidobacteria, followed by Leu and Val when added separately to milk. On the other hand, considerable reduction of acid production of $B$. infantis were observed when Ser or Asp was removed in omission test.

Therefore, it may be reasonable to conclude that some of the amino acids (Lys, Met, Ala, Leu, and Val) mentioned above contribute to stimulate the acid production of bifidobacteria with the smaller peptides produced by peptidases of bifidobacteria from the added peptides. Molecular weight of each peptide was presumed to be about 1,913 ( $\left.\mathrm{I}_{1}\right), 948$ ( $\left.\mathrm{I}_{2}\right), 2,319$ (II), 1,162 (III), and 1,163 (IV), respectively, by the amino acid composition.

It has long been recognized that peptides are of great nutritional value for many types of bacteria, and bacteria usually hydrolyse peptides and use the amino acids either directly for protein synthesis, or after further breakdown, as sources of nitrogen, carbon, or sulphur. On the other hand, there are many factors affecting the peptides transportation into bacterial cell. In terms of size of peptides, in general, peptides with more than 5 or 6 amino acid residues are not taken up by bacteria. Namely, as MILls and THomas') reported that the upper size limit for peptide transport through lactic streptococcal membranes was considered to be five or six residues, it may be impossible for the five peptides detected in the filtrate to be utilized directly by bifidobacteria as the nitrogen source when considering their molecular weights. However, it may be presumed that some of the smaller peptides derived from the decomposition of the peptides may be taken up directly into the bifidobacteria and utilized for their growth and acid production, although the data is lacking in this regard.

Accordingly, extracellular and intracellular peptidases of bifidobacteria may be considered to play an important role in the utilization of the peptides for their growth in the mixed incubation with $L$. casei.

\section{Acknowledgements}

We are grateful to the Morinaga Hoshikai (Morinaga Milk Industry Co., Tokyo) for providing financial support of this work.

\section{References}

1) Cheng C. - C. and T. Nagasaiva, Jpn. J. Zootech. Sci., 54: 740-747. 1983.

2) AOAC. "Official Methods of Analysis" 12 th ed. 251-256. Association of Official Agricultural Chemists, Washington, D.C. 1975.

3) DahiYa, R. S. and M. L. SPECK, J. Dairy Sci., 45: 607-612. 1962.

4) Markovitz, A. and D. Steinberg, J. Biol. Chem.; 228: 285-293. 1957.

5) Matheson, A. T. and B. L. Tattrie, Can. J. Biochem., 42: 95-103. 1964. 


\section{Stimulation on Acid Production of Bifidobacteria}

6) Аокі, K., E. Nakano and Y. Оні, Electrophoresis. 72-79. Hirokawa Publishing Co., Ltd. Tokyo. 1966.

7) Moffat, E. D. and R. I. Lytle, Anal. Chem., 31: 926-928. 1959.

8) Moore, S. and W. H. Stein, Methods in Enzymology. 6: 819-831. Academic Press Inc., New York. 1963.

9) Mills, O. E. and T. D. Thomas, N. Z. J. Dairy Sci. and Tech., 16: 43-55. 1981.

10) Hassinen, J. B., G. T. Durbin., R. M. Tomarelli and F. W. Bernhart, J. Bacteriol,, 62: 771777. 1951.

11) MADA, M., New Food Industry (Jpn), 24: 63-70. 1982.

\section{Lactobacillus casei の生産するペプチドおよび アミノ酸がビフィズス菌の生酸性に及ぼす影響}

\section{鄭 正權 - 長澤太郎}

玉川大学農学部, 町田市 194

ビフィズス菌をL.casei と混合培養した時,ビフィズ ス菌の発育性が著しく改善された，従ってこの原因を究 明するために空素源供給の観点から，L.casei に上り牛 乳中で形成される低分子空素化合物特にペブチドおよび 遊離アミノ酸を分離し，それらがビフィズス菌の生酸性 への効果について検討した．使用した菌種はBifidobacterium breve, B. infantis 扰よび L. casei であった。 培恙沪液の調製は DAHIYE ら, 遊離アミノ酸の除去は MARKOVITZ らの方法によった。主要な結果は次の通り である.

1. L. casei の 24 時間培養の培羕沪液 お。ひびの沪 液から遊離了ミ，酸を除去したものををれそれれ牛乳に添 加し，ビフィズス菌の生酸性への影響について検討した 結果, 両培養沪夜とも対照比比して生酸性促進の効果が 認められ, その促進効果は前者の培羔沪液の方がより大 であった。
2. 牛乳に各種フミ，酸の単独または混合添加,さら には除去試験の結果, ビフィズス菌の生酸性を著しく促 進したアミノ酸は，cystine で，その效果はB.breveよ り B. infantis の場合に大であった. Isoleucine おょび tryptophanはB. infantis の酸生産を阻害したが, cystine と isoleucinx あるいは tryptophan との混合添加では, isoleucine なは tryptophan の添加量の增加によって, cystine の促進効果は著しく阻害された.

3. L. casei による培㕠汇液を Sephadex G-15 でゲ 儿沪過し，生酸性促進効果を示す画分から，沪紙電気泳 動に上り5種のペプチドを単離したがそれらの分子量の 笽围は 948 から2,319であった。な拈それらのべプチド 中に見出された Lys, Met, Ala, Leu と Valがビフィ ズス菌の生酸性を促進するものと推察された。

日蓄会報，55（5)：339-349，1984 